\title{
Respected but Subordinated (A Study of Silenced Tunggu Tubang in South Sumatera)
}

\author{
Prawinda Putri Anzari ${ }^{1}$, Billy Sarwono ${ }^{2}$ \\ Department of Communication Science, Universitas Indonesia, Depok, Indonesia ${ }^{1,2}$ \\ $\left\{\underline{\text { billysarwono@gmail.com }}{ }^{2}\right\}$
}

\begin{abstract}
Similar to Bundo Kanduang in West Sumatra, Tunggu Tubang in Semende community, South Sumatra is the practice to task the eldest daughter in the family take care and preserve the customary traditions. On the one hand, tunggu tubang tradition puts women in a respectable position, but on the other hand, these tunggu tubang women do not have the power to carry out their duties, which is referred to by communication studies as a silenced group. A standpoint from the communication studies needs to be developed because communication is one of the important keys in the dissemination of cultural values and norms. The research question is how the silencing process occurs among tunggu tubang. Data collection was done from a one-year long observation and intensive interviews conducted in two weeks. Resource persons were selected purposively and two rich informants were selected to support the research. The results of the research show that tunggu tubang is a muted-group because they cannot voice opinions or anxiety about their position which has actually put obligation and pressures on them. They are taught to familiarize themselves with all the losses and sacrifices they have to make related to their position. This self-habituation is silencing tunggu tuban in the process of internalization. They are taught to accept, not to protest because it will harm them socially and spiritually.
\end{abstract}

Keywords: Tunggu Tubang, South Sumatra, Communication

\section{Introduction}

Indonesian society adheres to a patriarchal cultural system, which places men higher than their women. The dominance of men in all fields and all levels of society fosters gender bias. In a feminist perspective, gender inequality in society in several forms, namely subordination, women's double burden, negative stereotypes or labels for women, marginalization of women's roles and positions in society, and violence against women [1], [2]. Ironically, those women do not realize the existence of gender bias in their society. For example, Balinese women do not feel there is a gender imbalance, because what they do is an obligation, even though their religion actually places the position of women in a noble place due to their mystical powers [3], [4]. Likewise, women in East Nusa Tenggara, do not want to shame their extended family and support Belis's marriage customs, despite ignoring women's right to choose their future husband [5].

Similar things are found also in communities in Indonesia that adhere to matrilineal culture. Alfirahmi[6] explained that even though Minangkabau women in West Sumatra, had a noble 
position, most of them remained in the domestic domain and were subordinated. The strong dominance of male groups in Minangkabau then formed the way of thinking about the position of women in the public sphere. Another study of matrilineal society was carried out in the Semende area, in South Sumatra, which was about tunggu tubang traditions. The results of the study of Zaenal Arifin [7] show that tunggu tubang is a respected position, trusted to maintain the house and land of the family, thereby making their presence crucial to the survival of the community, and in the future it adheres to the norms, take care of large family home heritage and use it to strengthen kinship. Likewise, family assets in the form of rice fields will support the livelihood. As the caretaker of the family heritage, tunggu tubang has to stay and work at home, but she has no power to make decisions because the decision is in the hands of meraje or men from her mother's bloodline.

Although nowadays many women have jobs and high position, various studies prove that the customary succession law still prevails because that local communities support the continuity of this custom, Samadova [8] and Putri[9] and it is associated with values deemed relevant to religion. Gender construction, in this country, has given rise to inequalities that have been internalized in people's lives[10]. Therefore this research was carried out as an effort to reduce or minimize gender bias in various aspects of local culture life. Another reason is that not all parties realize that there has been gender inequality in this society, especially in local communities because they have not realized the potential that exists in women that can be developed to build and strengthen families, as well as communities. Theoretically, some of the results of previous studies on the position and role of women are more seen from the perspective of anthropology, sociology, customary law and still little is done through a communication perspective. This is despite the fact that communication is actually one of the important keys in the preservation of cultural values.

An interesting thing to examine the privilege given to tunggu tubang was not exercised according to the authority and freedom provided for them in reaching their dreams. Also, being tunggu tubang is not a responsibilty one can avoid, and the preservation of certain old values by the community makes it difficult for tunggu tubang to perform according to their customary power. In communication perspective, tunggu tubang is the muted group because male political domination has resulted in the male perception system becoming more dominant, and this can inhibit the free expression of alternative women's thinking.

The idea that women are muted groups was first expressed by Edwin Ardener[11]. According to him, in many studies of culture, women's positions and voices were not written in that culture. The silence occurs because of the low or lack of power or strength possessed by women in the community hierarchy. This resulted in them having difficulties when they wanted to speak out. According to Ardener, the structure that 'silences' actually exists in the dominant structure of the language, but the public is not aware thereof. Until one day, the 'structure' that was once invisible, became noticeable and visible.

Of course, muted group members can still speak out. The problem is whether they can voice their thoughts, desires, when, where they want, or whether they have to change their thinking and how to convey it according to the way the dominant group can accept it in their environment. According to Edwin Ardener \& Shirley Ardener [12].

"Their words (interests, and works), unless presented in a form acceptable to those in dominant groups, are often not considered as understandable by or as important to those in dominant groups. The speech of those in subordinate groups is often disrespected and their knowledge often not considered sufficient for decision or policymaking. Their experiences are often reinterpreted for them by others, and they are encouraged to see themselves as represented by the words and concepts in the dominant discourse." 
Cheris Kramarae and feminist experts see that women's thinking is not taken into account in society, and is not valued at all. One important element in this theory is language, as languages in certain cultures do not treat everyone equally, and not everyone contributes equally to the creation of the language. Kramarae believes that in the public sphere, women are less able to articulate or defend themselves than men because the words in the language and norm they use are the language of the dominant group. So that these words, perceptions, experiences, interests of the muted groups are continually ignored and eventually become unspoken and may not be thought of and realized by the muted group. Therefore, Kramarae demanded an 'arena' where the position of women and men was equal and balanced so that both had equal opportunities to compete. This expert explained that one of the disadvantages of muted group theory is that it does not explain exactly how silence occurs, therefore, some researchers try to combine it with other theories. Based on these thoughts, the researchers saw that the silenced tunggu tubang, which is the topic of this research, was established through a long process of value construction of gender bias traditional norms by local communities. Therefore, the researchers considered it necessary to use the theory of the construction of social reality [13]. They explained that the dialectical process occurs through three moments simultaneously, namely externalization, objectivation and internalization. Although society and social institutions are seen objectively, in reality, all social reality is built in subjective definitions in the interaction process. New objectivation can be realized through repeated affirmations given by other people or groups that have the same subjective definition area.

The final concept in the theoretical framework is the role and position of women in religion. Siti MulyaMusdah[6] explained that women in the Islamic discourse gave birth to two major schools, the first of which was that Islam did not recognize women's rights to leadership, both domestically and especially in the public sphere. The second was the thought that Islam recognizes that women's rights are equal to those granted to men, including in state leadership. In the end, the difference in the interpretation about women's leadership is due to the interpretation of the Qur'an and hadith, most of which has been done by men, so that did more to the marginalization of women.

Based on the various problems and theoretical thoughts mentioned above, the research question herein is how the process of silencing the tunggu tubang is? The theoretical assumptions that are built are: the roles and responsibilities of tunggu tubang occur through social construction or norm and values which are produced and reproduced in the family, or in educational, religious and social institutions. Internalization occurs in the application of values and norms related to religious teachings and division of labor, while objectivation occurs through passing on norms values which have been so deeply rooted that they are considered reasonable. Externalization occurs through adherence to religious teachings and cultural behavior carried out by all members of the community. Tunggu tubang has become a muted group because of the internalization of patriarchal values in the family, sanctions given to those who do not comply and cultural structures that have been further reinforcing this custom.

\section{Method}

The chosen paradigm is Critical Constructionism, which is similar to constructivist but emphasizes on the role of elite or dominant groups that construct problems not naturally, but according to the interests of the dominant group. Thus this point of view defends nondominant people who are the object of dominant and powerful groups [14]. The approach of this research is qualitative because researchers try to find the depth of a social problem and 
study individuals in their natural settings[15]. Analysis can be done at the time of data collection. Thus, researchers can immediately determine data saturation. Saturation occurs when there has been a repeat of the data at the time of data collection[16].

To obtain data, researchers observed local communities, when one of the researchers served as a teacher between 2014-2015. In 2017, researchers returned to interview several people who were deemed to be rich informants and were willing to be interviewed in depth. From this short list, researchers went further to select tunggu tubang informants who met the criteria of being married and having children. In addition, they had to have lived within the Semende region since they were born. Saturation occured when the researcher data collected from the informants had been saturated and similar, so so there was no need to increase the number of informants. After, finish collecting data, the researchers the data through several stages [17]. The goodness of the criterion is the source triangulation, done by conducting depth interviews with the Deputy Chief of tunggu tubang customary law Board and a Semende cultural observer. The results of interviews with the two people were used to complement and review the role of tunggu tubang as caretaker and implementing agent of customary values and norms.

\section{Result and discussion}

Semende or Semendo is one of the ethnic groups in South Sumatra Province, who domicile in Bengkulu and Lampung provinces. Most of these people are farmers, with rice, coffee, and rubber as main crops. In Semende tradition, despite the big number of the extended family members, the relationship between them is not always close, and big traditional ceremonies can be the tools to bring them closer and unite them.

The position of the eldest daughter as a tunggu tubang is based on the assumption that she is considered more mature, able to protect all family members and replace her parents. Tunggu tubang's existence has several meanings, among others: as a hard worker who can give income for the extended family. Secondly, tunggu tubang is the guardian of the extended family, or the heritage home which is a place for members to gather at, maintain relationship, and ensure thal all of their extended family members live well away from their hometown. Third, as a person who has character, authority, is respected, respected by society and is loyal, obedient to the elders and meraje. Finally, tunggu tubang must be able to manage the situations in the family, so that the bad situations become good and the good ones become even better.

Table 1. Background and Informants Perception of Tunggu Tubang

\begin{tabular}{lllll}
\hline & \multicolumn{2}{c}{ SN } & \multicolumn{2}{c}{ TS } \\
\hline 1. & Age & 53 years old & 40 years old & \\
\hline 2. & Education & Bachelor's Degree & Junior High School Graduate \\
\hline 3. & Occupation & Elementary school teacher & Housewife & \\
\hline 4. & $\begin{array}{l}\text { Social Status of } \\
\text { Economy }\end{array}$ & Middle class & $\begin{array}{l}\text { Low class, yet socially belongs to a } \\
\text { prominent class }\end{array}$ & \\
\hline 5. & Living Place & Urban area & Village area & \\
\hline 6. & $\begin{array}{l}\text { Perception of the } \\
\text { Position oftunggu } \\
\text { tubang }\end{array}$ & $\begin{array}{l}\text { Tunggu tubang } \\
\text { blessing }\end{array}$ & bring & $\begin{array}{l}\text { Tunggu tubang is a fate and } \\
\text { guardian of inheritance }\end{array}$ \\
\hline 7. & Role ofmeraje and & Customary law is fairly & Meraje, and husband are decision \\
\hline
\end{tabular}




\begin{tabular}{lll}
\hline male domination & $\begin{array}{l}\text { fair: women guarding } \\
\text { inheritance, } \\
\text { controllers } \\
\begin{array}{l}\text { Meraje is the decision } \\
\text { maker }\end{array}\end{array}$ & $\begin{array}{l}\text { Following orders of meraje is an } \\
\text { investment }\end{array}$ \\
\hline $\begin{array}{l}\text { Only men can speak at } \\
\text { traditional meetings }\end{array}$ & $\begin{array}{l}\text { Only men can speak at traditional } \\
\text { meetings }\end{array}$ \\
\hline
\end{tabular}

Related to the perception of tunggu tubang's positions, both informants are not realized that they are subordinated. SN told that the position brought blessings because she and her husband did not need to work hard to find capital to build houses or open rice fields. Meanwhile, another of SN's brothers must work hard after marriage. Therefore, according to $\mathrm{SN}$, the blessing she received must be enjoyed by her extended family, too. Being certain to obtain a gift or blessing and this destiny makes her sincerely carry out the task of tunggu tubang. According to SN, she must be sincere and never calculate profit and loss because she has received more inheritance and material from other family members. Besides that, the Semende community was known to be generous in entertaining guests who came to the house, so she had to spend all the expenses incurred for the guests who came. She said: "In Semende we say " Don't be gloomy ". Well, it means do not do this often, don't feel you have lost. .. If our relatives come, everything is gone in less than 15 minutes. Well, we do not mind..... "

Meanwhile, TS believes that become a tunggu tubang is fate, and it is her duties to respect her ancestors who opened lands in Semende and built settlements for their grandchildren. According to her, if a tunggu tubang neglects her duties, she does not respect her ancestors who have cleared land and developed their community in Semende. She said:

"... puyang awak was here. He was the one who started the Semende area. Because of puyang awak, there were other ancestors in Semende. That was why you are not allowed to carelessly leave the house and rice fields because it meant disrespect toward the ancestor. If there is no ancestor, we will not exist. "

Regarding the role and supervision carried out by the merajes, the two informants felt that women did not have the opportunity to speak, because only men in the line of their mothers had the opportunity to speak out in old custom. According to TS, following their orders is the same as making an investment because the meraje decision will be something that they can also enjoy later. According to $\mathrm{SN}$ and $\mathrm{TS}$, in various old custom meetings, meraje and the male relatives were in charge of welcoming guests, becoming spokespersons, conducting deliberations, etc. On the contrary, the role of women in family negotiations was non existing as they mostly had to work in the kitchen.

Not only in the traditional meetings, tunggu tubang cannot speak out in other occasions as well; for example according to $\mathrm{SN}$, she was not allowed to express that she had tried her best in performing her duties, but on the contrary, the meraje hold the right to impose customary sanctions for tunggu tubang who abandon their obligations. The merajes are so powerful that SN was sometimes had to let them or their extended family judge her. For TS, not only are the meraje in charge of many things, but they also play an important role in making decisions, such as in leasing rice fields or opening a coffee plantation. TS respected her husband so much because TS's husband was from a very old family in his village because her husband's tunggu tubang is already from the 9th generation. 
The reproductive process of gender inequality is carried out since childhood. SN and TS told that since childhood, their mother always demanded more from them to do the task of entertaining guests, cleaning the house, etc. compared to what was demanded from their sisters. Her mother said, even though SN's sister must also have the same abilities, SN's responsibilities were different because her skills as tunggu tubang to manage the kitchen and entertain the guests will be assessed by the extended family. Likewise now, the two informants reproduced the value of socialization by asking their children, the potential future tunggu tubang, to help them cook, wash the dishes, prepare the rice before cooking it, and take care of their little siblings. What SN said showed that her mother did not only conduct gender-biased socialization but also prepared the future tunggu tubang with education and capital which will help her to do her job once she became a tunggu tubang.

The research findings show that the views of tunggu tubang in interpreting their subordinate positions and recognizing male power in old custom structures are an internalization in which individuals identify with social institutions which were included in the local old custom structure. This system is then institutionalized and socialized into the sociocultural realm manifested in local customs. Patriarchal power for centuries has penetrated the body of customs. The local custom has become a form of social acceptance, constituting a concept agreed upon by the community as a form of social identity.

Socialization which has happened since the beginning refers to the cultural values embedded in religion which has also silenced the desire of women to raise issues when performing tasks as tunggu tubang. This situation cornered women and confirmed the subordination of women. There is a view that interprets Islam forbidding women through Alqur'an verses and hadiths to become leaders. The informants experienced then become a subjective reality that is formed through the internalization of various events, and gained through social interaction. For tunggu tubang, the world they see is a world embedded in cultural values and all customary structures in it. Full compliance toward meraje's words and obedience is compulsory: do not question whether it is true or not. The production of reproduction of cultural values becomes objectivation or institutionalization and habits for tunggu tubang. Unwittingly, fellow women (mothers) silenced interest and the future of the candidates, as if there was no other options for the candidates, like getting higher education or working and having a career they would dream of. Roles and duties and responsibilities are set up formed and determined by the dominant group as if they cannot be violated.

Finally, as an externalization, tunggu tubang become agents of socialization again in the event of socialization of the values and waiting position of the people. All values that have been embedded in the socialization process that a tunggu tubang gets (internalization) are then forwarded back to the tunggu tubang candidates. The candidates are provided with the same direction as has been previously given to their predecessors. This is a form of externalization of these values which will then become an objectivation for the candidates waiting for the next tubang.

Tunggu tubang is a muted group because after internalizing the value of silencing, they unconsciously continue to carry the subordinated status in the community and pass it on to next generation of women. The tunggu tubang fall into the muted-group category because of their position of not having the power and strength in their cultural group hierarchy. They cannot voice their opinions or anxiety about their position which actually constraints and brings harm to them. In fact, in some cases, tunggu tubang are taught to make themselves accustomed to injury and sacrifices related to their position as tunggu tubang. This selfhabituation is silencing tunggu tubang in the process of internalization. They are taught to accept, not protest because it will harm them socially and spiritually. Regarding language, the 
use of the term 'tunggu' which means waiting has shown the existence of subordination to the reality of tunggu tubang.

\section{Conclusions}

Tunggu tubang carries the meaning of someone being acknowledged as a hard-worker, a caretaker of family heritage, someone with high moral, authoritative, respected, capable and competent in managing the family and preserving the heritage of the extended family. However, in practice, this position does not have power over property and does not have the power to speak out. The tunggu tubang's big burden of responsibility which is then controlled and determined by the meraje is a structural silencing of the tunggu tubang female group.

Acknowledgments. This work is supported by Hibah PITTA 2018 funded by DRPM Universitas Indonesia. Nomor 5000/UN2.R3.1/HKP.05.00/2018.

\section{References}

[1] M. Richmond-Abbot, Gender Roles Over the Life Cycle, 2nd Editio. McGraw-Hill, 1992.

[2] N. Rofiah, "Kekerasan Dalam Rumah Tangga dalam Perspektif Islam," Wawasan J. Ilm. Agama dan Sos. Budaya, vol. 2, no. 1, pp. 31-44, Jun. 2017.

[3] N. Hannah, "Seksualitas dalam Alquran, Hadis dan Fikih: Mengimbangi Wacana Patriarki," Wawasan J. Ilm. Agama dan Sos. Budaya, vol. 2, no. 1, pp. 45-60, Jun. 2017.

[4] N. N. Rahmawati, "Perempuan Bali dalam Pergulatan Gender (Kajian Budaya, Tradisi, dan Agama Hindu),” J. Stud. Kult., vol. 1, no. 1, pp. 58-64, 2016.

[5] L. Purnama, "Apa Kabar Perempuan Daerah? (How are the women in the regions?)," J. Peremp., vol. 17, pp. 41-57, 2001.

[6] Alfirahmi, "Politisi Perempuan di Masyarakat Matrilineal Minangkabau (Studi Realitas Konstruksi Sosial Terhadap Peran Politisi Perempuan) [Female Politicians in Matrilineal Minangkabau Society (Study of the Reality of Social Construction on the Role of Female Politic," Universitas Indonesia, 2015.

[7] Z. Arifin, "Tunggu Tumbang: Marginalisasi Perempuan Semende," in Inaugural Conference International Indonesian Forum for Asian Studies (IIFAS) and the Faculty of Social and Political Sciences Andalas University: Creating ASEAN Futures 2015: Towards connected cross-border communities, 2015.

[8] H. Samadova, "Peran Tokoh Adat dalam Mempertahankan Adat Tunggu Tubang pada Masyarakat Semendo di Desa Sinar Semendo Kelurahan Labuhan Kecamatan Tanjung Senang Bandar Lampung," Universitas Bandar ampung, 2017.

[9] L. P. Handayani, "Penerapan Sistem Pewarisan Adat Tunggu Tubang di Daerah Semendo, Kabutpaten Muara Enim, Sumatera Selatan.," Universitas Indonesia, 2008.

[10] K. Hasni, "Perjalanan Panjang Perempuan Dalam Budaya," Jurnal Perempuan, 2015. [Online]. Available: https://www.jurnalperempuan.org/wacana-feminis/perjalananpanjang-perempuan-dalam-budaya.

[11] E. Griffin, A. Ledbetter, G. Sparks, and E. Langan, A First Look at Communication Theory. New York: McGraw-Hill, 2019.

[12] S. W. Littlejohn and K. A. Foss, Encyclopedia of Communication Theory. Thousand 
Oaks: SAGE, 2009.

[13] P. L. Berger and T. Luckmann, The Social Construction of Reality. A Treatise in the Sociology of Knowledge. New York: A Double Day Anchor Book, 1966.

[14] R. Heiner, Social Problems. An Introduction to Critical Constructionism. New York: Oxford University Press, 2006.

[15] M. Hennink, I. Hutter, and A. Bailey, Qualitative Research Methods. California: SAGE, 2011.

[16] B. G. Glaser and A. L. Strauss, Discovery of Grounded Theory: Strategies for Qualitative Research. Brunswick: Aldine Publishing Company, 1967.

[17] J. W. Creswell, Research Methods: Qualitative and Quantitative: Mixed Methods Approach. Thousand Oaks: SAGE, 2014. 